\title{
A fast-moving [2]rotaxane whose stoppers are remote from the copper complex core
}

Ulla Létinois-Halbes, David Hanss, John M. Beierle, Jean-Paul

Collin, Jean-Pierre Sauvage*

\section{Supplementary Information}

\section{EXPERIMENTAL:}

All experiments have been carried out under inert gas if not stated otherwise. Common reagents and materials were purchased from commercial sources. Thin layer chromatography has been performed on alumina (Alunimiumoxide, standard 90) or silica gel from MERCK, Art. 7748 Kieselgel $60 \mathrm{PF}_{254}$. The column chromatography has been carried out with MERCK Art. 9385 Kieselgel $60(0.04-0.06)$. The solvents used for the column chromatography have been distilled before use

NMR spectra were recorded using a forward multinuclear probe head with z-gradients. The proton spectra were recorded at a frequency of $400 \mathrm{MHz}$ and the ${ }^{13} \mathrm{C}$ spectra at $100.577 \mathrm{MHz}$. During recording ${ }^{13} \mathrm{C}$ spectra protons were decoupled. Decoupling showed no line narrowing effect. The chemical shift is given in ppm with respect to TMS. The ${ }^{13} \mathrm{C}$ spectra in solvents other than $\mathrm{CDCl}_{3}$ were referenced to the $\Xi$ scale using the recommended IUPAC $\Xi$ values for ${ }^{13} \mathrm{C}=25.145020 \mathrm{MHz}$. The coupling constants are given in hertz.

The multiplets have been indicated by the following abbreviations: s (singlet), d (doublet), $\mathrm{t}$ (triplet), q (quadruplet), dd (doublet of doublets), m (multiplet).

The ESI-MS spectra were performed with triple quadripole spectrometer in positive mode.

Preparation and characterization of compounds:

5,5'-Bis(bromomethyl)-2,2'-bipyridine $3^{6}$ 
${ }^{1} \mathrm{H}-\mathrm{NMR}\left(\mathrm{CDCl}_{3}\right): \delta=4.53\left(\mathrm{~s}, 4 \mathrm{H}, \mathrm{CH}_{2} \mathrm{Br}\right) ; 7.85(\mathrm{dd}, J=8.4 \mathrm{~Hz}, J=2.4 \mathrm{~Hz}, 2 \mathrm{H}$, bpy H4, 4'); 8.40 (d, $J=8.4 \mathrm{~Hz}, 2 \mathrm{H}$, bpy H3, 3'), 8.68 (d, $J=2.4 \mathrm{~Hz}, 2 \mathrm{H}$, bpy H6, 6'). ${ }^{13} \mathrm{C}-\mathrm{NMR}: \delta=29.5$; $120.5 ; 134.0 ; 137.8 ; 149.3 ; 156.1$.

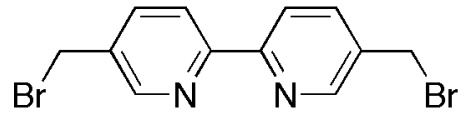

8-(2H-Tetrahydropyran-2-yloxy)-3n ${ }_{6}^{3}$-dioxaoctan-1-ol ${ }^{7}$

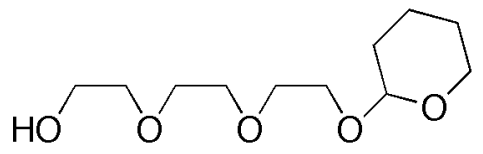

${ }^{1} \mathrm{H}-\mathrm{NMR}\left(\mathrm{CDCl}_{3}\right): \delta=1.47-1.80\left(\mathrm{~m}, 6 \mathrm{H}, \mathrm{CH}_{2} \mathrm{CH}_{2} \mathrm{CH}_{2} \mathrm{CH}_{2} \mathrm{O}\right) ; 2.58(\mathrm{~s}, 1 \mathrm{H}, \mathrm{OH}) ; 3.58-3.62$ $(\mathrm{m}, 1 \mathrm{H}) ; 3.66-3.72\left(\mathrm{~m}, 11 \mathrm{H}, \mathrm{OCH}_{2} \mathrm{CH}_{2} \mathrm{O}\right) ; 3.82-3.87\left(\mathrm{~m}, 2 \mathrm{H}, \mathrm{CH}_{2} \mathrm{CH}_{2} \mathrm{CH}_{2} \mathrm{CH}_{2} \mathrm{O}\right) ; 4.62$ (t, $\left.1 \mathrm{H}, J=3 \mathrm{~Hz}, \mathrm{OCHCH}_{2}\right) .{ }^{13} \mathrm{C}-\mathrm{NMR}: \delta=19.4 ; 25.4$. 30.5; 61.5; 62.2; 66.6; 70.3; 70.5; 70.6; 72.6; 98.9 .

4 and 5

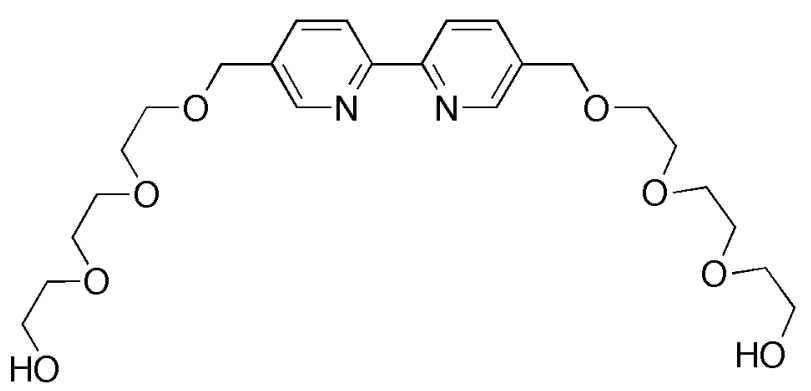

8-(2H-Tetrahydropyran-2-yloxy)-3n ${ }_{6}^{3}$-dioxaoctan-1-ol (2.769 g, $\left.11.8 \mathrm{mmol}\right)$ was dissolved in $200 \mathrm{~mL}$ tetrahydrofuran and sodium hydride $(60 \%$ suspension in mineral oil, $2.36 \mathrm{~g}, 60$ mmol) was added. The reaction mixture was stirred at $80^{\circ} \mathrm{C}$ for two hours. 5,5'Bis(bromomethyl)-2,2'-bipyridine 3 (1.012 g, $2.9 \mathrm{mmol}$ ) was added and the resulting light brown suspension was stirred under reflux for 15 hours. The reaction mixture was then allowed to cool to room temperature. Water was added and the $\mathrm{pH}$ of the aqueous phase was 
adjusted to $\mathrm{pH} 7$ with diluted $\mathrm{HCl}$. The aqueous phase was then extracted with five $50 \mathrm{~mL}$ portions of chloroform. The combined organic layers were dried over $\mathrm{MgSO}_{4}$ and the solvent was removed under reduced pressure. For the removal of the THP protecting groups, the crude product was redissolved in $100 \mathrm{~mL}$ ethanol and a few drops of concentrated $\mathrm{HCl}$ were added. The solution was refluxed for three hours and the ethanol was then removed. The remaining oil was dissolved in $30 \mathrm{~mL}$ dichloromethane and $30 \mathrm{~mL}$ water were added. The aqueous phase was extracted three times with $30 \mathrm{~mL}$ portions of chloroform. The organic layers were dried over $\mathrm{MgSO}_{4}$ and the solvents were removed under reduced pressure. The remaining yellow oil was purified by column chromatography (neutral aluminium oxide, $\mathrm{CH}_{2} \mathrm{Cl}_{2} / \mathrm{MeOH} 97: 3, \mathrm{R}_{\mathrm{f}}=0.22$ ). The product was obtained in $64 \%$ yield.

${ }^{1} \mathrm{H}-\mathrm{NMR}\left(\mathrm{CDCl}_{3}\right): \delta=3.59-3.74\left(\mathrm{~m}, 24 \mathrm{H}, \mathrm{CH}_{2} \mathrm{CH}_{2} \mathrm{OCH}_{2}\right) ; 4.62(\mathrm{dd}, J=4.5 \mathrm{~Hz}, J=1.6 \mathrm{~Hz}$, $4 \mathrm{H}, \mathrm{OCH}_{2}$-bpy); 7.79 (dd, $J=8.1 \mathrm{~Hz}, J=2.4 \mathrm{~Hz}, 2 \mathrm{H}$, bpy H4, 4'); 8.35 (d, $J=8.1 \mathrm{~Hz}, 2 \mathrm{H}$, bpy H3, 3’); 8.67 (d, $J=2.4 \mathrm{~Hz}, 2 \mathrm{H}$, bpy H6, 6'). ${ }^{13} \mathrm{C}-\mathrm{NMR}: \delta=66.3 ; 69.0 ; 69.3 ; 69.8 ; 70.6 ; 76.6$; 120.9; 133.8; 136.6; 148.5; 150.2; 155.2. ESI-MS: $481.25(\mathrm{M}+) ; 406.20$.

6

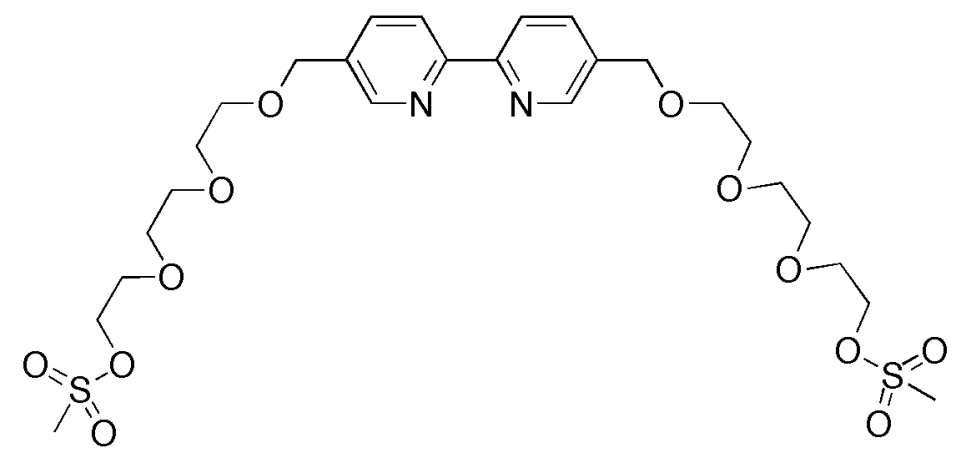

Compound 5 (946 mg, $1.9 \mathrm{mmol}$ ) was dissolved in $100 \mathrm{~mL}$ dichloromethane and triethylamine $(2.81 \mathrm{~mL}, 20 \mathrm{mmol})$ was added. The solution was cooled to $-5^{\circ} \mathrm{C}$ and $1 \mathrm{~mL}$ of a $1 \mathrm{M}$ solution of methanesulfonic chloride $\left(\left(760 \mu \mathrm{L} \mathrm{MsCl}\right.\right.$ in $\left.1 \mathrm{~mL} \mathrm{CH}_{2} \mathrm{Cl}_{2}\right)$ was added dropwise to the solution. The reaction mixture was maintained at $-5^{\circ} \mathrm{C}$ for three hours and was then allowed to warm to room temperature. After one additional hour $50 \mathrm{~mL}$ of water were added and the aqueous phase was extracted three times with $50 \mathrm{~mL}$ portions of chloroform. The combined organic layers were dried over $\mathrm{MgSO}_{4}$ and the solvents removed under reduced pressure. According to the ${ }^{1} \mathrm{H}-\mathrm{NMR}$ the crude product was considered to be pure enough to be used for the next step without further purification. 
${ }^{1} \mathrm{H}-\mathrm{NMR}\left(\mathrm{CDCl}_{3}\right): \delta=3.12\left(\mathrm{~s}, 6 \mathrm{H}, \mathrm{CH}_{3} \mathrm{~S}\right) ; 3.66-3.67\left(\mathrm{~m}, 16 \mathrm{H}, \mathrm{OCH}_{2} \mathrm{CH}_{2} \mathrm{O}\right) ; 3.74-3.76(\mathrm{~m}$, 4H, $\mathrm{CH}_{2} \mathrm{OCH}_{2}$-bpy); 4.30-4.36 (m, 4H, $\mathrm{CH}_{2} \mathrm{CH}_{2} \mathrm{OS}$ ); 4.62 (s, 4H, $\mathrm{CH}_{2}$-bpy); 7.79 (dd, J=7.8 Hz, $J=2.1 \mathrm{~Hz}, 2 \mathrm{H}$, bpy H4, 4'); 8.35 (d, $J=7.8 \mathrm{~Hz} ; 2 \mathrm{H}$, bpy H3, 3'); 8.61 (d, J=2.1 Hz, 2H, bpy H6, 6'). ${ }^{13} \mathrm{C}-\mathrm{NMR}: \delta=31.5 ; 37.5 ; 37.7 ; 46.1 ; 66.2 ; 69.0 ; 69.2 ; 69.8 ; 70.6 ; 120.8 ; 133.7$; $136.5 ; 148.6$.

7

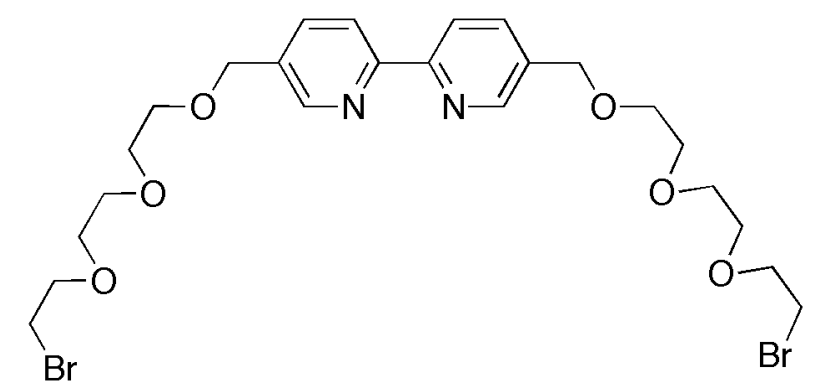

Compound 6 (1.145 g, $1.8 \mathrm{mmol})$ was dissolved in $50 \mathrm{~mL}$ acetone and $\mathrm{LiBr}(1.737 \mathrm{~g}, 20$ mmol) was added in one portion. The solution was stirred at room temperature and its evolution followed on TLC. After five hours the conversion was complete. The solvent was removed under reduced pressure and the remaining product was taken up in dichloromethane and water $(30 \mathrm{~mL}$ each). The aqueous layer was extracted three times with $30 \mathrm{~mL}$ portions of chloroform and the combined organic layers were dried over $\mathrm{MgSO}_{4}$. The product was chromatographied over alumina $\left(\mathrm{CH}_{2} \mathrm{Cl}_{2} / \mathrm{MeOH}, 97: 3, \mathrm{R}_{\mathrm{f}} 0.15\right)$. The product was isolated with $57 \%$ yield (two steps).

${ }^{1} \mathrm{H}-\mathrm{NMR}\left(\mathrm{CDCl}_{3}\right): \delta=3.45\left(\mathrm{t}, J=6.3 \mathrm{~Hz}, 4 \mathrm{H}, \mathrm{CH}_{2} \mathrm{Br}\right) ; 3.62-3.67\left(\mathrm{~m}, 16 \mathrm{H}, \mathrm{O}-\mathrm{CH}_{2}-\mathrm{CH}_{2}-\mathrm{O}\right)$; 3.74 (t, 4H, J=6.3 Hz, O-CH2- $\mathrm{CH}_{2}-\mathrm{Br}$ ) ; 4.59 (s, 4H, CH2-bpy) ; 7.69 (dd, 2H, J=2.4 Hz, $J=8.1 \mathrm{~Hz}$, bpy H4, 4') ; 8.32 (d, 2H, $J=8.1 \mathrm{~Hz}$, bpy H3, 3') ; 8.57 (d, 2H, J=2.4 Hz, bpy H6, $\left.6^{\prime}\right) .{ }^{13} \mathrm{C}-\mathrm{NMR}: \delta=30.4 ; 69.8 ; 70.5 ; 70.6 ; 70.7 ; 71.2 ; 120.7 ; 133.7 ; 136.4 ; 148.6 ; 155.4$. ESIMS: $607.1(\mathrm{M}+)$; 514.3; 413.3. H.R.M.S. for $\mathrm{C}_{24} \mathrm{H}_{35} \mathrm{Br}_{2} \mathrm{~N}_{2} \mathrm{O}_{6}$ calc.: 607.0838, found 607.0896. 


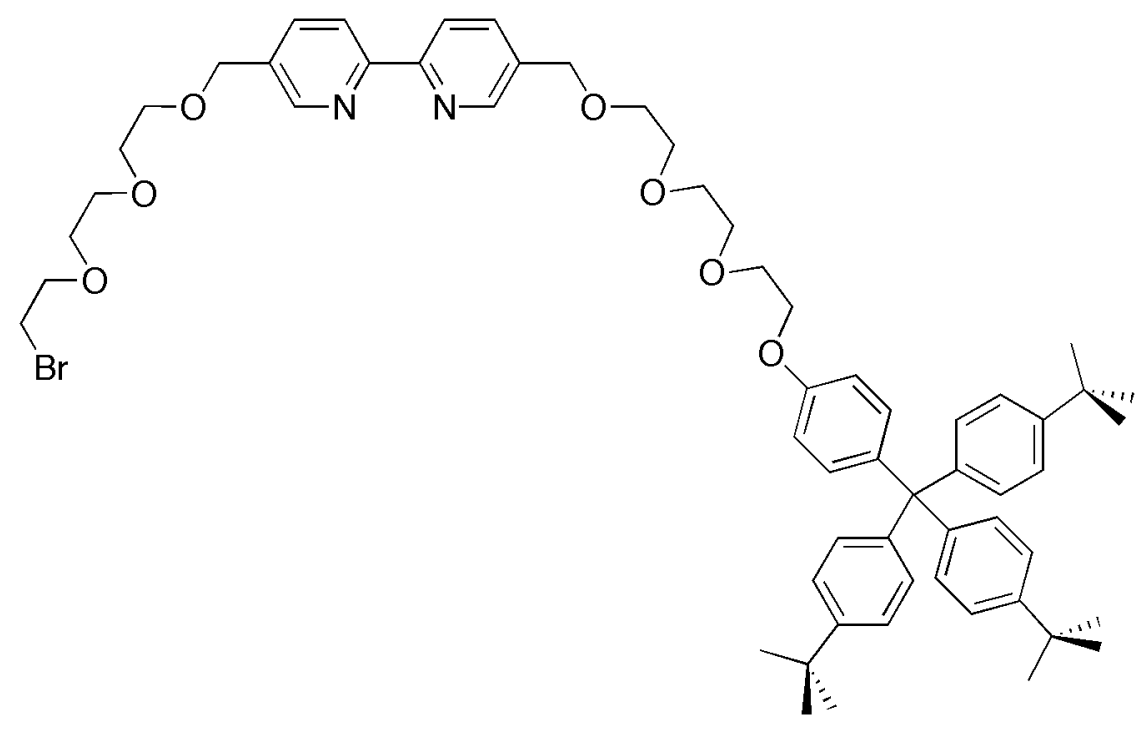

The stopper $8(248 \mathrm{mg}, 492 \mu \mathrm{mol})$ and $\mathrm{NaH}$ (60\% suspension in mineral oil, $29 \mathrm{mg}, 738$ $\mu \mathrm{mol})$ were suspended in $10 \mathrm{~mL}$ THF and stirred at $50^{\circ} \mathrm{C}$ for two hours. Then, a solution of 7 (993 mg, $1.64 \mathrm{mmol}$ ) in $2 \mathrm{~mL}$ THF was added via canula. The mixture was stirred at $50^{\circ} \mathrm{C}$ for 24 hours. After cooling to room temperature, water $(10 \mathrm{~mL})$ was added and the $\mathrm{pH}$ was adJusted to $\mathrm{pH} 7$ with $0.5 \mathrm{M} \mathrm{HCl}$. The aqueous phase was extracted three times with $5 \mathrm{~mL}$ portions $\mathrm{CH}_{2} \mathrm{Cl}_{2}$ and three times with $5 \mathrm{~mL}$ portions ethyl acetate. The combined organic phases were dried over $\mathrm{MgSO}_{4}$ and the solvents removed under reduced pressure. The crude product was chromatographied (Pentane/AcOEt/MeOH, 70:28:2, $\mathrm{R}_{\mathrm{f}}=0.63$ ) and was isolated in $30 \%$ yield. $62 \%$ of the starting material 7 was recovered intact.

${ }^{1} \mathrm{H}-\mathrm{NMR}\left(\mathrm{CDCl}_{3}\right): \delta=1.29(\mathrm{~s}, 27 \mathrm{H}, \mathrm{tBu}) ; 3.47\left(\mathrm{t}, J=6.2 \mathrm{~Hz}, 2 \mathrm{H}, \mathrm{CH}_{2} \mathrm{Br}\right) ; 3.68-3.72(\mathrm{~m}, 16$ $\mathrm{H}, \mathrm{OCH}_{2} \mathrm{CH}_{2} \mathrm{O}$ ); 3.81-3.84 (m, 4H, $\mathrm{CH}_{2} \mathrm{CH} 2 \mathrm{OAr}$ ); 4.10 (t, J=6.1 Hz, 2H, $\mathrm{BrCH}_{2} \mathrm{CH}_{2} \mathrm{O}$ ); 4.64 (s, 4H, bpy-CH $\left.\mathrm{H}_{2} \mathrm{O}\right) ; 6.77$ (d, $\left.J=8.7 \mathrm{~Hz}, 2 \mathrm{H}, \mathrm{O}-\mathrm{Ar}\right) ; 7.06$ (d, $J=8.4 \mathrm{~Hz}, 6 \mathrm{H}, \mathrm{Ar}$ ); 7.22 (d, $J=8.7$ $\mathrm{Hz}, 6 \mathrm{H}, \mathrm{Ar}$ ); 7.25 (d, J=8.4, 2H, Ar) ; 7.69 (d, $J=8.1 \mathrm{~Hz}, 2 \mathrm{H}$, bpy H4, 4'); 8.36 (d, $J=8.1 \mathrm{~Hz}$, 2H, bpy H3, 3'); 8.63 (br s, 2H, bpy H6, 6'). ${ }^{13} \mathrm{C}-\mathrm{NMR}: 31.4 ; 34.3 ; 63.0 ; 67.2 ; 69.8$; 70.6 ; $70.7 ; 70.8 ; 71.2 ; 113.1 ; 120.8 ; 124.0 ; 130.7 ; 132.2 ; 133.8 ; 136.5 ; 139.7 ; 144.1 ; 148.3$; 148.6 ; 155.5 ; 156.5. ESI-MS : $1031.5(\mathrm{M}+) ; 819.5\left(-\mathrm{Br},{ }^{\mathrm{t}} \mathrm{BuPh}\right) ;$ 764.6. H.R.M.S. for $\mathrm{C}_{61} \mathrm{H}_{77} \mathrm{~N}_{2} \mathrm{O}_{7} \mathrm{Br}$ calc: 1031.4973 , found 1031.4983 .

Preparation of the prerotaxane $\left[\mathbf{1 1}^{+}\right] \mathbf{P F}_{\mathbf{6}}^{-}$ 


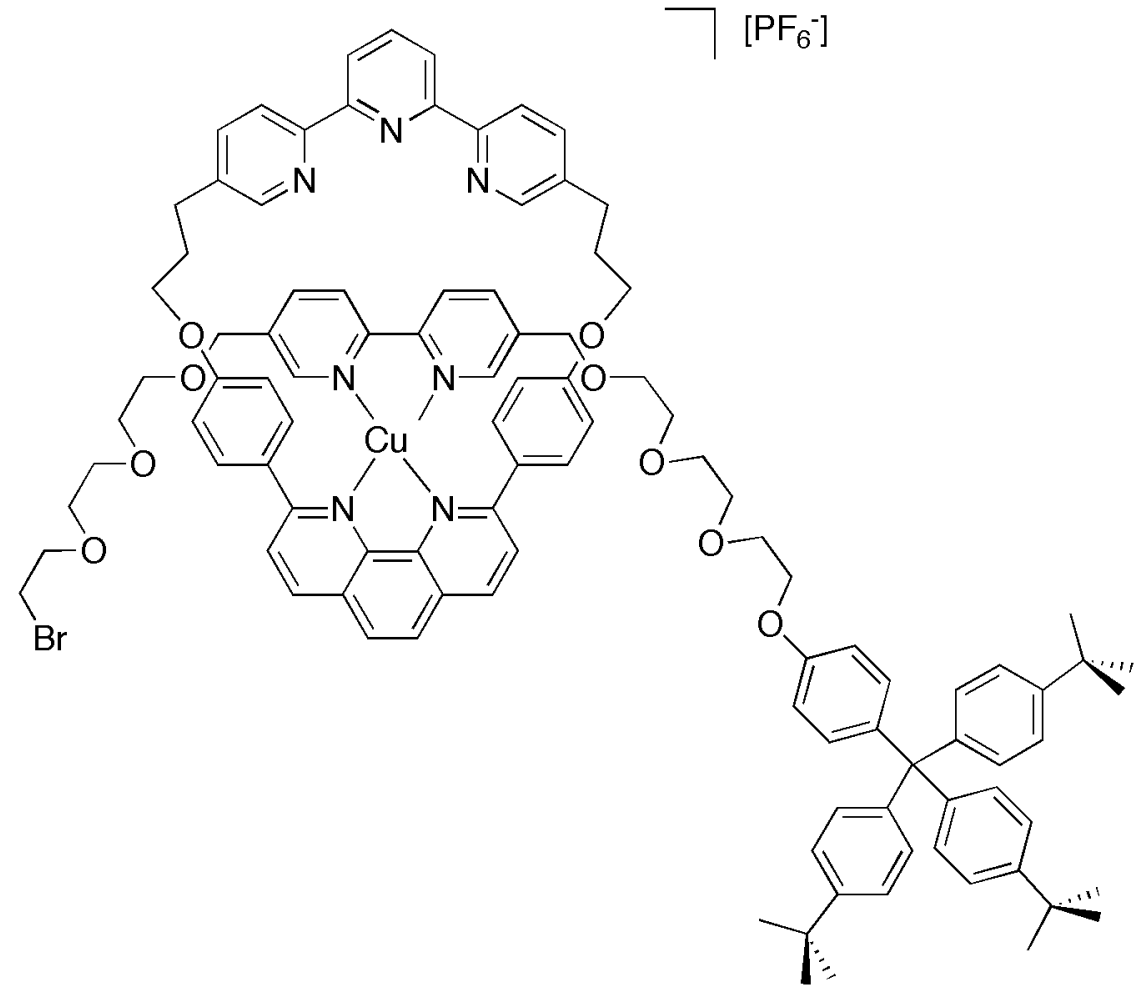

$\left[\mathrm{Cu}(\mathrm{MeCN})_{4}\right] \mathrm{PF}_{6}(27 \mathrm{mg}, 73 \mu \mathrm{mol})$ was dissolved in $2 \mathrm{~mL}$ anhydrous and degassed acetonitrile. Macrocycle 1 (44 mg, $66 \mu \mathrm{mol}$ ) was dissolved in $5 \mathrm{~mL}$ anhydrous and degassed dichloromethane and the solution was added to the copper(I) solution. The mixture turned to brown immediately. After 30 minutes of stirring under argon a solution of 9 (67.9 mg, 66 $\mu \mathrm{mol})$ in $5 \mathrm{~mL} \mathrm{CH}_{2} \mathrm{Cl}_{2}$ was added via canula. The colour of the reaction mixture turned to deep red. Stirring was continued for three hours. The solvents were removed under reduced pressure under argon. A red solid remained which was used for the next reaction step without purification.

${ }^{1} \mathrm{H}-\mathrm{NMR}\left(\mathrm{CDCl}_{3}\right): \delta=1.28(\mathrm{~s}, 27 \mathrm{H}, \mathrm{tBu}) ; 2.21-2.26\left(\mathrm{~m}, 4 \mathrm{H}\right.$, terpy- $\left.\mathrm{CH}_{2} \mathrm{CH}_{2} \mathrm{CH}_{2}-\mathrm{O}\right)$; 2.98$3.02\left(\mathrm{~m}\right.$, terpy- $\left.\mathrm{CH}_{2} \mathrm{CH}_{2} \mathrm{CH}_{2}-\mathrm{O}\right) ; 3.46\left(\mathrm{t}, J=6.0 \mathrm{~Hz}, 2 \mathrm{H}, \mathrm{CH}_{2} \mathrm{Br}\right) ; 3.68-3.70(\mathrm{~m}, 10 \mathrm{H}$, $\left.\mathrm{OCH}_{2} \mathrm{CH}_{2} \mathrm{O}\right) ; 4.63$ (t, $J=3 \mathrm{~Hz}, 4 \mathrm{H}$, bpy-CH $\left.\mathrm{CH}_{2} \mathrm{O}\right) ; 6.22(\mathrm{~d}, J=6.7 \mathrm{~Hz}, 4 \mathrm{H}, A r) ; 6.77$ (d, $J=8.7 \mathrm{~Hz}$, $2 \mathrm{H}, \mathrm{CH}_{2} \mathrm{O}$-stopper $\left.A r\right) ; 7.07$ (d, $J=6.6 \mathrm{~Hz} ; 10 \mathrm{H}, A r$ and stopper- $\left.A r\right) ; 7.25$ (d, J=6.6 Hz, 8H, stopper- $A r) ; 7.50$ (dd, $J=5.7 \mathrm{~Hz}, J=3.0 \mathrm{~Hz}, 2 \mathrm{H}$, bpy H4, 4'); 7.71 (d, $J=5.7 \mathrm{~Hz}, 2 \mathrm{H}$, bpy H3, 3'); 7.74 (s, 2H, phen H5, 6); 7.81 (dd, $J=8.1 \mathrm{~Hz}, J=2.1 \mathrm{~Hz}, 2 \mathrm{H}$, terpy H4, 4' '); 7.95 (t, $J=8.4$ Hz, 1H, terpy H4'); 8.04 (d, J=8.4 Hz, 2H, phen H3, 8); 8.27 (d, J=8.4 Hz, 2H, phen H4, 7); 8.39 (d, J=8.4 Hz, 2H, terpy H3', 5'); 8.57 (s, 2H, terpy H6, 6') ); 8.67 (s, 2H, bpy H6, 6'); $8.75(\mathrm{~d}, J=8 \mathrm{~Hz}, 2 \mathrm{H}$, terpy $\mathrm{H} 3,3$ ''). 


\section{Rotaxane 1}

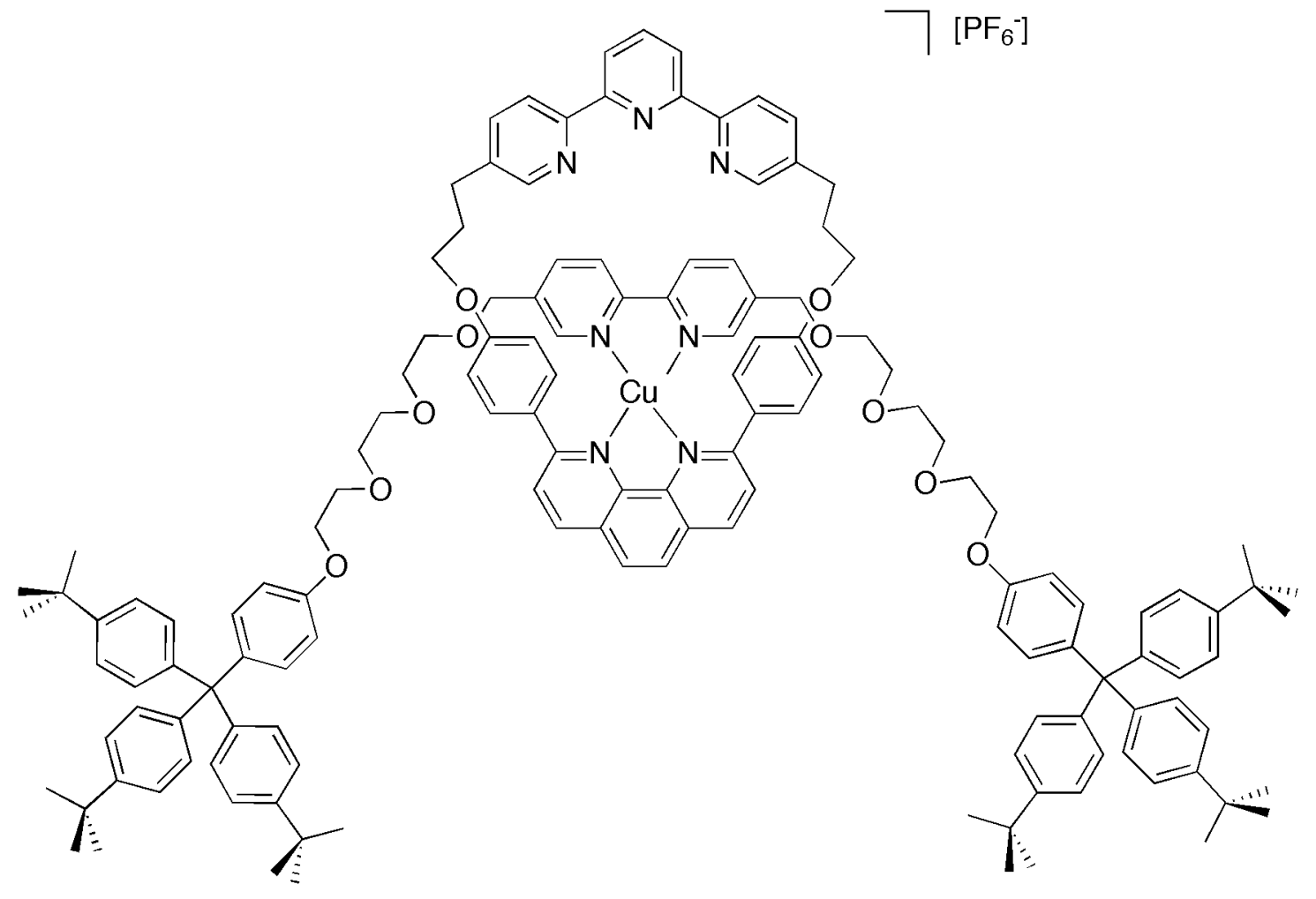

$\left[\mathbf{1 1}^{+}\right] \mathbf{P F}_{6}{ }^{-}$and the stopper $(35 \mathrm{mg}, 70 \mu \mathrm{mol})$ were placed in a two-necked round flask under argon and $5 \mathrm{~mL}$ degassed DMF were added. A suspension of caesium carbonate (195 mg, 600 $\mu \mathrm{mol})$ was added during a period of two hours. The reaction mixture was stirred for fifteen hours at $45^{\circ} \mathrm{C}$. The colour turned green. DMF was removed under reduced pressure and the residue was dissolved in $5 \mathrm{~mL}$ dichloromethane and $5 \mathrm{~mL}$ water. The aqueous phase was extracted five times with chloroform and diethylether. For the demetallation the crude product was dissolved in $4 \mathrm{~mL}$ dichloromethane and a solution of $\mathrm{KCN}(214 \mathrm{mg}, 660 \mu \mathrm{mol})$ in $4 \mathrm{~mL}$ water was added. After vigorous stirring during 30 minutes, the phases were separated, the aqueous layer was extracted three times with $5 \mathrm{~mL}$ portions of dichloromethane and the combined organic layers were dried and the solvent removed under reduced pressure. The crude product was purified by column chromatography (pentane/ethyl acetate/methanol/triethylamine: 70:27:2:1) and was recovered with $32 \%$ yield.

UV-VIS: $\mathrm{c}=1.4 \mu \mathrm{M}, \mathrm{CH}_{2} \mathrm{Cl}_{2}, \mathrm{~A}: 0.523(\varepsilon=3775) .{ }^{1} \mathrm{H}-\mathrm{NMR}\left(\mathrm{CDCl}_{3}\right): \delta=1.28(\mathrm{~s}, 54 \mathrm{H}, \mathrm{tBu})$; 2.21 (m, 4H, t-py- $\left.\mathrm{CH}_{2} \mathrm{CH}_{2} \mathrm{CH}_{2}-\mathrm{O}\right) ; 3.00$ (m, t-py- $\left.\mathrm{CH}_{2} \mathrm{CH}_{2} \mathrm{CH}_{2}-\mathrm{O}\right) ; 3.49-3.70$ (m, $\mathrm{OCH}_{2} \mathrm{CH}_{2} \mathrm{O}$ ); 3.98 (t, $J=6 \mathrm{~Hz}, 4 \mathrm{H}, \mathrm{t}-\mathrm{py}-\mathrm{CH}_{2} \mathrm{CH}_{2} \mathrm{CH}_{2}-\mathrm{O}$ ); 4.63 (t, $J=3 \mathrm{~Hz}, 4 \mathrm{H}$, bpy-CH$-\mathrm{O}$ ); $6.76(\mathrm{~d}, J=6.3 \mathrm{~Hz}, 4 \mathrm{H}$, stopper $A r H) ; 7.06$ (d, $J=9 \mathrm{~Hz}, 4 \mathrm{H}$, stopper-ArH); 7.08 (d, J=8.9 Hz, 
4H, $A r) ; 7.15$ (d, J=8.4 Hz, 12H, stopper Ar); 7.22 (d, J=8.4 Hz, 12H, stopper- $A r H) ; 7.55$ (s, 2H, phen H5, 6); 7.69 (dd, $J=7.8 \mathrm{~Hz}, J=1.5 \mathrm{~Hz}, 2 \mathrm{H}$, bpy H4, 4'); 7.79 (dd, $J=6.0 \mathrm{~Hz}, J=1.5$ $\mathrm{Hz}, 2 \mathrm{H}$, terpy H4, 4' '); 7.97 (t, $J=5.7 \mathrm{~Hz}, 1 \mathrm{H}$, terpy H4'); 8.04 (d, $J=8.4 \mathrm{~Hz}, 2 \mathrm{H}$, phen H3, 8); 8.26 (d, $J=8.4 \mathrm{~Hz}, 2 \mathrm{H}$, phen H7, 4); 8.31 (d, $J=8.7 \mathrm{~Hz}, 4 \mathrm{H}$, phen-Ar); 8.35 (d, J=7.8 Hz, 2H, bpy H 3, 3'); 8.37 (d, J=7.8 Hz, 2H, terpy H3', 5'), 8.58 (d, J=8.1 Hz, 2H, terpy H3, 3' '); 8.61 (d, $J=1.8 \mathrm{~Hz}, 2 \mathrm{H}$, terpy H6, 6' '); 8.62 (d, J=1.2 Hz, 2H, bpy H6, 6'). ${ }^{13} \mathrm{C}-\mathrm{NMR}: \delta=29.4$; $29.7 ; 31.4 ; 34.3 ; 45.9 ; 51.0 ; 56.9 ; 57.3 ; 57.7 ; 58.7 ; 59.1 ; 70.8 ; 114.9 ; 120.2 ; 120.9 ; 121.6$; $124.0 ; 129.2 ; 130.7 ; 134.9 ; 137.6 ; 137.9 ; 138.5 ; 148.2 ; 149.2 ; 150.1 ; 150.4 ; 150.9 ; 151.5$; $152.0 ; 152.6 ; 153.0 ; 153.4 ; 153.6$.

ESI-MS: $2132.2(\mathrm{M}+) ; 1707.8\left(\mathbf{1 1}^{+}\right)$; $1454.9\left(\mathbf{1 2}^{+}\right)$; $1031.5\left(\mathbf{1 1}^{+}\right)$. H.R.M.S. for $\mathrm{C}_{143} \mathrm{H}_{156} \mathrm{~N}_{7} \mathrm{O}_{10}$ calc.: 2132.1941, found 2132.1751.

Cyclic voltammetry: For the cyclic voltammetry analysis, $5 \mathrm{mg}$ of $\left[\mathbf{1 2}^{+}\right] \mathbf{P F}_{\mathbf{6}}{ }^{-}$were redissolved in $2 \mathrm{~mL}$ dichloromethane and added to a solution of $1 \mathrm{mg}\left[\mathrm{Cu}(\mathrm{MeCN}] \mathrm{PF}_{6}\right.$ in $1 \mathrm{~mL}$ acetonitrile. The solution got immediately deep red. The solvents were evaporated under reduced pressure and redissolved in acetonitrile. The cyclic voltammetry was carried out in acetonitrile, using $\mathrm{nBu}_{4} \mathrm{NPF}_{6}(0.1 \mathrm{M})$ as electrolyte. The measurements were carried out using a platinum electrode and a silver wire as reference electrode. 